\title{
Tribute to Frédéric Siordet
}

Mr. Frédéric Siordet, former member and Vice-President of the ICRC and one of the institution's leading figures, died on 30 January 1991.

Mr. Melchior Borsinger, former ICRC Delegate General for Europe and North America and recipient of the Henry Dunant Medal, was his friend. In the following tribute to this great champion of the Red Cross, Mr. Borsinger expresses the admiration and affection shared by all at the ICRC and in the Movement as a whole who had the opportunity to appreciate Frédéric Siordet's ability, fine mind and human qualities.

$$
* * *
$$

Frédéric Siordet, who was a member of the ICRC from 1951 to 1979 and Vice-President of the institution for several terms during that period, passed away on 30 January 1991. His death leaves an immense void.

Though unassuming in manner, Frédéric Siordet displayed an astonishing array of talents. He was the son of a pastor, and went into law; the result was a mind firmly rooted in both the spiritual and the temporal. An enlightened humanist, great music-lover and gifted writer, his rather British sense of humour stood in contrast to his acute Continental wit and way of thinking.

He practised law for many years in Paris, where he served as legal adviser to the Swiss Legation. When the Legation left Paris in the wake of the German invasion in 1940 to follow the French government to Bordeaux and later Vichy, Frédéric Siordet remained in German-occupied Paris to look after Swiss interests in a quasi-consular capacity. 
He left Paris in 1943 so that his daughters could carry on their studies in Switzerland. He was appointed an adviser to the ICRC, and we quickly became friends.

Frédéric Siordet was a delightful colleague, invariably courteous and sensitive. His great modesty concealed a profound knowledge of human nature, with its failings, its vices and virtues. His mischievous humour and kind-heartedness were a great comfort to those who knew him and worked with him during a painful and sombre period in human history.

When the war was over, he took part in the work preparatory to the revision of the 1929 Geneva Conventions, and in particular the drawing up of a new, fourth Convention for the protection of civilians in time of war. Here his experience in wartime Paris stood him in good stead.

In the early 1950s, working together with Jean Pictet, Claude Pilloud, René-Jean Wilhelm and Jean de Preux, he made a major contribution to the Commentary on the Conventions. Their task was often lightened by Frédéric Siordet's humour, for example when he wrote a "Summary of the Conventions in P". I especially remember a marvellous screed entitled "Plaintively Pondering Pilloud" which, if memory serves correctly, began: "Poor Pilloud profoundly perplexed prickly problem protection pugnacious prisoners propounds perilous proposal postpone pursuit pending Protecting Power's propositions".

Frédéric Siordet represented the ICRC in many countries and at a number of International Conferences of the Red Cross. He was also the author of the book Inter Arma Caritas, an outstanding analysis of ICRC activities during the Second World War.

But in addition to being an intellectual, Frédéric Siordet was also a man of action. He undertook many important missions for the ICRC, not least a journey around the world in 1945-46 during which he visited all the National Societies in Asia, Australia and Central and North America - no easy feat given conditions in the immediate aftermath of the war.

The winter of 1957 took him to India, South-East Asia and China, then to the Soviet Union and Poland. He explained to the leaders of the countries he visited the ICRC's position regarding the status of mainland China and Taiwan - a very sensitive issue at the time. Indeed, it was China under Chiang Kai-shek's Kuomintang that had signed the 1949 Geneva Conventions but it was the People's Republic under Mao Zedong that ratified them. This circumstance had seriously jeopardized the holding of the 19th International Conference of the 
Red Cross in Delhi, which made Frédéric Siordet's mission all the more important.

In 1952, while ICRC Vice-President, Frédéric Siordet acted as spokesman for the ICRC's delegation to the 18th International Conference of the Red Cross in Toronto. The Conference was held while the Korean war was at its height and the National Societies and governments of the Communist countries made virulent attacks on the ICRC, accusing it, in short, of being nothing but an instrument of capitalist imperialism. Frédéric Siordet's courageous, lucid and objective defence of the ICRC before the plenary assembly of the Conference on this occasion will remain a monument to the Red Cross spirit.

Another fine example of Frédéric Siordet in action was when Georges Olivet, a young and promising ICRC delegate, was killed - in particularly tragic and diplomatically delicate circumstances - in Katanga in 1962. Frédéric Siordet, then a member of the International Committee, volunteered to go out to the Congo and bring back the delegate's mortal remains.

Frédéric Siordet was also a keen sportsman and was one of the leading members of the ICRC's skittles club. I remember well the many tennis matches and games of billiards we played together.

Frédéric Siordet's death has deprived us of an outstanding defender of humanity, whose sincerity, honesty and simplicity, coupled with a keen intellect, won over to the Red Cross cause many sceptics and even opponents; a man who inspired a whole new generation to follow in his footsteps.

Melchior Borsinger 